\title{
Neutrophil count in the gingival wound healing process after apitoxin gel application (gingival wound healing model on Wistar rats)
}

\author{
Urfa Tabtila*, Swastiana Eka Yunita*, Muhammad Nabil Pratama**, Juni Handajani*** $\square$ \\ *Dentistry Study Program, Faculty of Dentistry, Universitas Gadjah Mada, Yogyakarta, Indonesia \\ **Faculty of Animal Science, Universitas Gadjah Mada, Yogyakarta, Indonesia \\ ***Department of Oral Biology, Faculty of Dentistry, Universitas Gadjah Mada, Yogyakarta, Indonesia \\ ***JI Denta No 1, Sekip Utara, Yogyakarta, Indonesia; $\bowtie$ correspondence: junihandajani@ugm.ac.id
}

Submitted: $16^{\text {th }}$ July 2018; Revised: $19^{\text {th }}$ March 2019; Accepted: $26^{\text {th }}$ May 2020

\begin{abstract}
Periodontal disease has a high prevalence in Indonesia. Gingival disease is a periodontal disease if it is severe, requires surgical therapy called a gingivectomy. Surgical periodontal procedures lead to a gingival wound that is usually treated using a periodontal pack. Periodontal pack has no curative property in general but assists in a wound healing process by protecting tissues. Neutrophils are inflammatory cells that act as a host's first defense against infectious pathogens and they are important in wound healing. Wound healing can be accelerated by apitoxin gel from honeybee Apis mellifera species. The aim of this study was to determine the effectiveness of apitoxin gel on neutrophil count on gingival wound healing process. Medical bee venom powder (Umea, Sweden) was mixed with double-distilled water to prepare a concentration of $0.01 \%$ bee venom. The solution was mixed with $10 \%$ propylene glycol, $0.01 \%$ methylparaben, and $3 \%$ CMC-sodium. Thirty six gingiva of 3 month-old male Wistar rats (weighing 200-250 gram) were injured using punch biopsy ( $3 \mathrm{~mm}$ in diameter). They were treated in 4 groups: apitoxin gel, apitoxin gel with a periodontal pack, NSAIDs Flamar ${ }^{\circledR}$ gel with periodontal pack, and a periodontal pack. Three Wistar rats from each group were euthanized and their jaws were taken after 48 hours treatment to make histology slides with Hematoxylin Eosin (HE) staining. Neutrophil counts were observed. The data were analyzed using Anova test with $95 \%$ confidence level. The results showed there were significan defferebces among 4 groups $(p<0.05)$. The highest neutrophil count on the $2^{\text {nd }}$ day was found in the apitoxin gel induced the $2^{\text {nd }}$ day of gingival wound healing process.
\end{abstract}

Keywords: apitoxin gel; Apis mellifera; gingival wound healing process; neutrophils

\section{INTRODUCTION}

Periodontal disease has a high prevalence in Indonesia, which reaches $96.58 \%$ in all age groups. ${ }^{1}$ Periodontal disease occurs in periodontal tissues that consist of gingiva, periodontal ligament, cementum, and alveolar bone. ${ }^{2}$ Gingiva is a part of oral mucosa that covers the cervical area of teeth. ${ }^{3}$ Gingiva as the outermost periodontal tissue often experiences injury due to a pathological or traumatic condition that causes a damage to gingival anatomical structure. ${ }^{4} \mathrm{~A}$ severe gingival disease should be treated by gingivectomy. ${ }^{5}$ Gingivectomy is a procedure of periodontal surgical treatment by excreting gingival tissue, ${ }^{6}$ aiming to remove gingival pockets or gingival enlargement to obtain a normal gingiva in terms of both health and aesthetic functions. ${ }^{2}$ Surgical periodontal procedures lead to a gingival wound that is usually treated using a periodontal pack. A periodontal pack only serves as a gingival protector from movement and bacteria ${ }^{7}$ without accelerating the wound healing process.

One of the wound healing factors is neutrophil. Neutrophils lead the first wave of host defense to infection or tissue damage. ${ }^{8}$ They increase dramatically on the first and second days after the wound appears. ${ }^{9}$ Neutrophils migrate to the sites of inflammation for killing pathogens and removing cellular debris. ${ }^{10}$ Neutrophils stimulate the release of various growth factors and cytokine signals, also act as a chemoattractant for inflammatory cells. An increase in neutrophil infiltration can lead to a prolonged release of proteolytic enzymes, free radicals, and proinflammatory cytokines, causing chronic wounds. On the other hand, a decrease in 
neutrophils obstructs wound healing process. This way, a balanced neutrophil count is needed. ${ }^{9}$

In the last few decades, researchers have been paying much attention to natural ingredients with less side effects, ${ }^{11}$ but those studies focus on active plant materials. Insects are currently 7000 times less frequently studied than plants, ${ }^{12}$ whereas insects have many useful active substances for human health. One of the insects that have many products for health is honey bee. One of the honey bee species is Apis mellifera. It is a superior honey bee breed in Indonesia because it is more domesticated than other honey bee species. ${ }^{13}$ Apis mellifera produces various products, such as honey, royal jelly, propolis, bee pollen, bee wax, and bee venom. ${ }^{14}$ Bee venom has 18 pharmacologically active components, including enzymes, peptides, and other small molecules that are very beneficial for health. ${ }^{15}$ Melittin is a major component of bee venom, ${ }^{16}$ which supresses inflammation by inhibiting the activity of enzymatic phospholipase (PLA). ${ }^{15}$ Bee venom has been widely used as a pain-relieving therapy and inflammatory disease treatment. It effectively treats allergies, scars, burns, and skin diseases. In addition, bee venom has been proven to facilitate keratinocyte migration and reduce the secretion of proinflammatory cytokines. ${ }^{16}$ Bee venom is a safe medicine for humans. A cytotoxic test of bee venom against Vero cell showed inhibition concentration 50 (IC50) result of $156.8 \mu \mathrm{g} / \mathrm{ml}$. Thus, bee venom is proven to be non-toxic. ${ }^{17}$

The purpose of this study was to determine the effect of apitoxin gel on neutrophil count on the second day of gingival wound healing process. This study used the bee venom of Apis Mellifera honey bee to prepare the apitoxin gel. The result of this study is expected to show an animal utilization, especially insects, in medicine. The apitoxin gel is expected to be clinically applied on human in the future.

\section{MATERIALS AND METHODS}

This study was a pure laboratory experiment with a post-test only control group design. The study procedure was approved by the research ethics committee of the Faculty of Dentistry, Universitas Gadjah Mada, Yogyakarta, with the issuance of the ethical clearance letter number 001438/KKEP/ FKG-UGM/EC/2018.

The Apitoxin gel was prepared by mixing the bee venom powder (Umea, Sweden) with doubledistilled water to obtain a concentration of the bee venom of $0.01 \%$. The solution was mixed with $10 \%$ propylene glycol as a solvent, and $0.01 \%$ methylparaben as a preservative. The $3 \%$ CMC$\mathrm{Na}$ as a basis was pounded until the gel mass was formed. Then, $0.01 \%$ bee venom solution was gradually added to the gel base. The apitoxin gel was prepared at the Laboratory of Solid Dosage Formulation Technology, Faculty of Pharmacy, Universitas Gadjah Mada.

The subjects of this study were 363 monthsold male Wistar rats, which weighed 200-250 grams. The in vivo experiment was performed at the Integrated Research and Testing Laboratory Universitas Gadjah Mada. The gingival wound healing model was prepared on all the subjects by punching the labial gingival of the mandibular central incisor using punch biopsy which was 3 $\mathrm{mm}$ in diameter. The subjects were divided into 4 groups of applications. Each group consisted of 9 Wistar rats. Group I was treated with the apitoxin gel. Group II was given the combination of the apitoxin gel and periodontal pack fixation. Group III was treated using the NSAIDs Flamar ${ }^{\circledR}$ gel and periodontal pack fixation. Group IV was treated with the periodontal pack fixation only.

The Wistar rats were euthanized after 48 hours by decapitation method, and the jaws were taken to make the histology slides with Hematoxylin Eosin (HE) staining at the Laboratory of Histology, the Faculty of Medicine, Public Health, and Nursing, Universitas Gadjah Mada. The histology slides were observed using a binocular light microscope with 400x magnification at the Integrated Research Laboratory, Faculty of Dentistry, Universitas Gadjah Mada. The neutrophil count was calculated from 5 field areas. The data were analyzed using Saphiro-Wilk, Levene's, and Anova tests with 95\% confidence level. 


\section{RESULTS}

In this study, we observed the neutrophil count as an indicator of the gingival wound healing process. Observations were performed using a binocular light microscope with 400x magnification. The observations were made in 5 fields of view. The examples of one field from each group can be seen in Figure 1. The mean neutrophil count on the $2^{\text {nd }}$
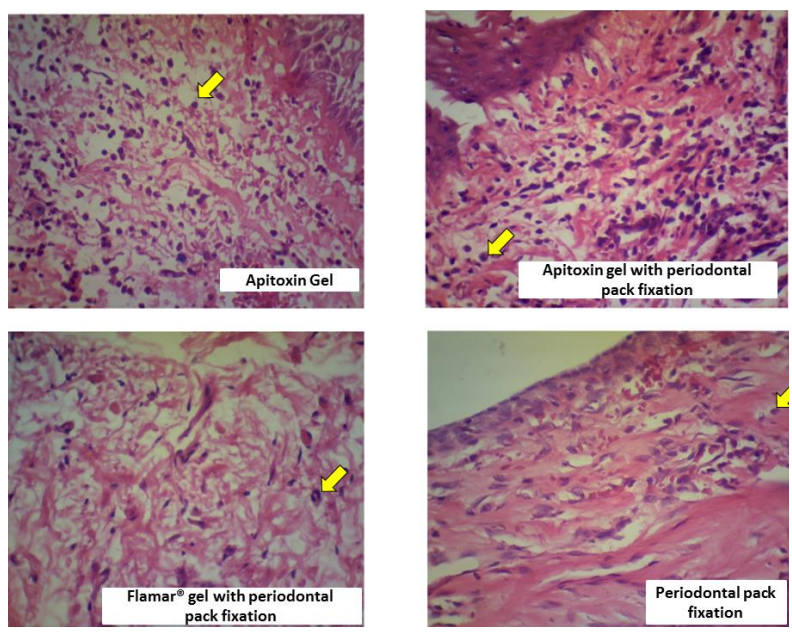

Figure 1. The histological features of rats' gingiva in each treatment group. Yellow arrows point to neutrophills on each treatment group. day was shown in Figure 2. The highest neutrophil count on the 2nd day was found in the apitoxin gel grop. The results of the data analysis for normality and homogeneity, as well as the ANOVA test are shown in Table 1.

The normality test resulted in $p>0.05$, thus the data were declared to be normally distributed. The homogeneity test result showed that the data were homogeneous. Further analysis using ANOVA showed $p=0.043$ or indicated significant differences among the groups. The least significant difference

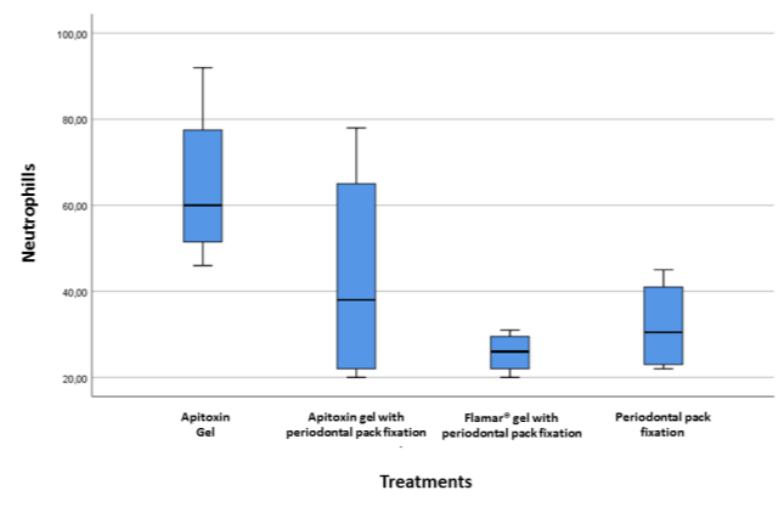

Figure 2. Mean neutrophill counts in each treatment group

Table 1. The results of normality (Shapiro-Wilk), homogeneity (Levene's), and ANOVA tests

\begin{tabular}{lcccc}
\hline \multicolumn{1}{c}{ Group } & df & Shapiro-Wilk & $\begin{array}{c}\text { Levene test } \\
\text { Sig }\end{array}$ & $\begin{array}{c}\text { Anova } \\
\text { Sig }\end{array}$ \\
\hline Apitoxin gel & 4 & 0.533 & & \\
Apitoxin gel with periodontal pack fixation & 4 & 0.446 & 0.052 & 0.043 \\
Flamar® gel with periodontal pack fixation & 4 & 0.925 & & \\
Periodontal pack fixation & 4 & 0.441 & & \\
\hline
\end{tabular}

Table 2. Summary of LSD post-hoc analysis $(p<0.05)$

\begin{tabular}{lccc}
\hline Apitoxin gel & $\begin{array}{c}\text { Apitoxin gel with } \\
\text { periodontal pack } \\
\text { fixation }\end{array}$ & $\begin{array}{c}\text { Flamar® gel with } \\
\text { periodontal pack } \\
\text { fixation }\end{array}$ & $\begin{array}{c}\text { Periodontal pack } \\
\text { fixation }\end{array}$ \\
\hline Apitoxin gel & 0.120 & 0.009 & 0.024 \\
$\begin{array}{l}\text { Apitoxin gel with periodontal } \\
\text { pack fixation }\end{array}$ & & 0.183 & 0.377 \\
$\begin{array}{l}\text { Flamar@ gel with periodontal } \\
\text { pack fixation }\end{array}$ & & 0.627 \\
Periodontal pack fixation & & \\
\hline
\end{tabular}


(LSD) post- hoc analysis result is shown in Table 2 to determine the difference between each group.

The results in Table 2 show that there were significant differences among the groups treated using the apitoxin gel, periodontal pack fixation, and also Flamar® gel with periodontal pack fixation. However, the result was not significantly different between the groups treated using the apitoxin gel and the apitoxin gel with periodontal pack fixation.

\section{DISCUSSION}

The process of wound healing will not occur if there is no inflammatory phase..$^{18}$ The inflammatory phase is characterized by an increase in inflammatory cells, one of which is neutrophil cell. Neutrophil cells appear and converge in the wound area, then stimulate the release of various growth factors and cytokine signals. In fact, balanced neutrophil counts are required. ${ }^{9}$ An excess neutrophil infiltration promotes a chronic injury, requiring it to be controlled. However, a lack of neutrophil cells leads to an inhibition of wound healing process. In fact, a wound healing process begins with the formation of blood stem in the injured tissue. It is followed by the inflammatory phase on the $1^{\text {st }}$ to the $3^{\text {rd }}$ day, the proliferative phase on the $3^{\text {rd }}$ to the $7^{\text {th }}$ day, and the remodeling phase on the $7^{\text {th }}$ until the $14^{\text {th }}$ day after injury. ${ }^{18}$

The results showed that the neutrophil counts of the group treated using the apitoxin gel and apitoxin gel with periodontal pack fixation were higher than those treated using the Flamar® gel group with periodontal pack fixation and periodontal pack fixation only. The high neutrophil count was caused by an acute inflammatory response to the apitoxin gel chemicals. Meanwhile, activation of the inflammasome by the bee venom induced a caspase-1-dependent inflammatory response, characterized by recruitment of neutrophils to the site, or envenomation. The inflammasome is dispensable for the allergic response to bee venom. ${ }^{19}$ The apitoxin gel (bee venom) induced caspase-1 dependent, which caused the neutrophils to be released into the wound area. ${ }^{19}$ However, the high neutrophil count was not a pathological effect of the apitoxin gel, but it played an important role in the acute inflammatory response by maintaining the sterility in the wound area, removing debris of dead cells, also repairing tissues. ${ }^{19}$

The mean neutrophil count resulted from the group treated using the Flamar® gel with periodontal pack fixation was the lowest. Flamar® gel is a standardized NSAIDs gel. The effect of NSAIDs on wound healing is only seen in the initial period which is on the first 5 days during the peak of the inflammatory phase..$^{20}$ The low neutrophil count is in line with a theory of Golan, ${ }^{21}$ stating that NSAIDs affects a wound healing through three pathways, one of which is to lower leukocyte recruitment and decrease the production of leukocyte inflammatory mediator.

The group of non-drug periodontal pack fixation had a fairly low mean neutrophil count and showed a significant difference with the group treated using the apitoxin gel as well as that treated using the apitoxin gel with periodontal pack fixation. However, the mean outcomes of this group had no significant differences compared to those of the groups treated using the Flamar ${ }^{\circledR}$ gel with periodontal pack fixation. In fact, periodontal pack has no curative effect. It only serves to protect postoperative tissue without affecting the amount of healing factors. Periodontal pack helps wound healing process by reducing the possibility of postoperative infection and bleeding..$^{22}$

\section{CONCLUSION}

Apitoxin gel can induce neutrophil count on the second day of Wistar rats' gingival wound healing process. Based on this research, further study is needed to find out the effectiveness of apitoxin gel as a gingival wound healing agent. Further research can be done with modifications such as longer treatment time, different comparison drugs, or other inflammatory agents.

\section{ACKNOWLEDGMENTS}

The authors would like to thank the Ministry of Research, Technology and Higher Education of the Republic of Indonesia through the Student Creativity Program Grant and all parties who assisted the process of conducting this research. 


\section{REFERENCES}

1. Lestari DP, Wowor VN, Tambunan E. Hubungan tingkat pengetahuan kesehatan gigi dan mulut dengan status kesehatan jaringan periodontal pada penyandang diabetes melitus tipe 2 di RSUD Manembo-nembo Bitung. e-GIGI. 2016; 4(2): 188-195.

doi: 10.35790/eg.4.2.2016.13926

2. Newman MG, Takei HH, Klokevold PR, Carranza FA, Newman and Carranza's Clinical Periodontology, Missouri: Elsevier; 2016, 51-66, available at https://www- clinicalkeycom.ezproxy.ugm.ac.id/\#!/content/book/ 3s2.0B9780323523004000035? index Override $=$ GLOBAL

3. Scheid RC, Weiss G. Woelfel's Dental Anatomy, 8th ed. Philadelphia: Wolters Kluwer Lippincott Williams \& Wilkins; 2012.

4. Polimeni G, Xiropaidis AV, Wikesjo UME. Biology and principles of periodontal wound healing/regeneration. Periodontol 2000. 2006; 41: 30-47. doi: 10.1111/j.1600-0757.2006.00157.x.

5. Low SB, Laser in Periodontal Surgery in Convistar RA, Principle and Practice of Laser in Dentistry, $2^{\text {nd }}$ ed., Missouri: Elsevier; 2016, 51-66, available at https://www-clinicalkeycom.ezproxy.ugm.ac.id/\#!/content/book/ 3-s2.0-B9780323297622000048

6. Cohen ES. Atlas of cosmetic and reconstructive periodontal surgery, 3rd ed. Shelton: People's Medical Publishing House; 2009.

7. Bird DL, Robinson DS. Modern dental assisting, 12th ed. Missouri: Elsevier; 2017.

8. Oliveira S, Rosowski EE, Huttenlocher A. Neutrophil migration in infection and wound repair: going forward in reverse. Nat Rev Immunol. 2016; 16(6): 378-391.

doi: 10.1038/nri.2016.49

9. Paul, Willi and Sharma, Chandra P. Advances in wound healing materials: science and skin engineering. Shawbury: Smithers Rapra Technology; 2015.

10. Rosales C, Demaurex N, Lowell CA, UribeQuerol, E. Neutrophils: Their Role in Innate and Adaptive Immunity. J Immunol Res. 2016; 2017: 9748345. doi: 10.1155/2017/9748345

11. Hartini PS, Dewi N, Hayatie L. Ekstrak ikan haruan (Channa striata) menurunkan jumlah makrofag pada fase inflamasi proses penyembuhan luka. Dentofasial. 2015; 14(1): 6-10.

12. Leandro LF, Mendes CA, Casemiro LA, Vinholis AHC, Cunha WR, Almeida RD, Martins CHG. Antimicrobial activity of apitoxin, melittin and phospholipase A2 of honey bee (Apis mellifera) venom against oral pathogens. An Acad Bras Cienc. 2015; 87(1): 147- 155. doi: 10.1590/0001-3765201520130511

13. Situmorang, Rospita OP, Hasanudin A. Panduan manual budidaya lebah madu. Parapat: Balai Penelitian Kehutanan Aek Nauli; 2014.

14. Shiddiq A, Minarti S, Junus M. Quality of pollen grain and bee bread assessment of honey bees (apis mellifera) in the mango trees plantation area. Malang: Brawijaya University Press; 2013.

15. Ali MAAM. Studies on bee venom and its medical uses. International Journal of Advancements in Research \& Technology. 2012; 1(2): 69-83.

16. Han SM, Park KK, Nicholls YM, Macfarlane N, Duncan G. Effects of honeybee (Apis mellifera) venom on keratinocyte migration in vitro. Pharmacogn Mag. 2013; 9(35): 220-226. doi: 10.4103/0973-1296.113271

17. Moselhy WA, El-Didamony SE, Taher FA, Mohamed AF, Metwalley KM, Zayed AB. Evaluation of anticancer potentials of bee free venom and chitosan nano-conjugated one: in vitro study. IJSRM. 2017; 5(4): 5253-5262. doi: $10.18535 / \mathrm{ijsrm} / \mathrm{v} 5 \mathrm{i} 4.01$

18. Kusumastuti E, Handajani J, Susilowati $\mathrm{H}$. Ekspresi COX-2 dan jumlah neutrofil fase inflamasi pada proses penyembuhan luka setelah pemberian sistemik ekstrak etanolik Rosela (Hibiscus sabdariffa) (studi in vivo pada Tikus Wistar). Majalah Kedokteran Gigi Indonesia. 2014; 21(1): 13-19.

doi: $10.22146 /$ majkedgiind. 8778 
Majalah Kedokteran Gigi Indonesia. August 2020; 6(2): 65 - 70 ISSN 2460-0164 (print)

ISSN 2442-2576 (online)

19. Palm NW, Medzhitov R. Role of the inflammasome in defense against venoms. Proc Natl Acad Sci U S A. 2013; 110(5): 1809-1814. doi: 10.1073/pnas.1221476110

20. Slatter, Douglas H. Textbook of small animal surgery. Philadelphia: Elsevier Science; 2003.

21. Golan, David E. Principles of pharmacology: the pathophysiologic basis of drug therapy. Philadelphia: Lippincott Williams \& Wilkins; 2008.
22. Newman MG, Takei HH, Klokkevold PR, Carranza, Fermin A. Carranza's Clinical Periodontology, $12^{\text {th }}$ ed. Canada: Elsevier Saunders; 2014. 